\title{
The Changing Concept of War and America's Defence Policy
} Ferdi Güçyetmez

\begin{abstract}
The Changing Concept of War and America's Defence Policy

Abstract

States fight by nature to get their hegemony accepted. Therefore, world history begins with wars and conflicts. Unequal power exchanges between states have existed since the day humanity began to live together. Since the states reveal these dynamics, establishing sovereignty has survived from the first generation to the present. So why did societies that want to dominate each other find the solution in conflict and war? This study attributes this problem to the invariance of human nature, such as Thucydides, and a dogmatic reason in the consciousness of increasing humanity's powers through fear. Although progress has been made in line with the systematically changing theories of war with the lessons learned from the methods of war between the Spartans and the Athenians, the following fact must be revealed: "Even if the technological development and economy of mankind progress, the war that this man dogmatically carries in does not change his nature, it only changes the methods of war." This study reveals the change in war policies and defence in line with the data obtained by observing the conditions of Americanbased change of the political order transitioning to multipolar world order.
\end{abstract}

Keywords: hegemony, new methods of war, Wallerstein, hard power, America

\author{
Değișen Savaş Konsepti ve Amerika'nın Savunma \\ Politikası \\ $\ddot{O} z$
}

Devletler, hegemonik savașlarını baskılamak ve kabul ettirmek için doğası gereği savaşır. Bu nedenle, dünya tarihi savaşlar ve çatışmalar ile başlar. Devletlerarası eşit olmayan güç değişimleri, insanlığın bir arada yaşamaya başladığı günden itibaren vardır. Devletler, dinamiklerini ortaya koyduğu için egemenlik kurma çalışmaları ilk nesilden günümüze kadar gelebilmiştir. Peki, birbiri üzerinde egemenlik kurmak isteyen toplumlar çareyi neden çatışmakta ve savaşmakta bulmuşlardır? Bu sorunsal, çalışmada Tukidides gibi, insan doğasının değişmezliğine, insanlığın korkuyla yönlendirilmesiyle güçlerini artırma bilincindeki dogmatik nedene bağlnmaktadır. Spartalılar ve Atinalılar arasındaki savaş yöntemlerinden çıkarılan derslerle sistematiği değişen savaş kuramları doğrultusunda ilerleme kaydedilse de şu gerçek ortaya konulmalıdır: "İnsanlığın teknolojik gelişimi ve ekonomisi ilerleme kaydetse dahi bu insanın dogmatik olarak içinde taşıdığı savaş doğasını değiştirmez sadece savaşın yöntemlerini değiştirir.' Bu çalışmada, çok kutuplu dünya düzenine geçiş yapan politik düzenin ABD merkezli değişimi gözlemleyerek elde edilen veriler doğrultusunda savaş politikaları ve savunma tercihlerinin değişiminini ortaya koyulmuştur.

Anahtar Sözcükler: hegemonya, yeni savaş metotları, Wallerstein, sert güç, Amerika

\section{Introduction}

Henry Kissinger (1994, p. 6) begins his book, namely Diplomacy, by stating that "A country with the strength, will, intellectual and moral power that will reshape the entire international system according to its values is emerging every century as if it were a law of nature." With the spread of regional-scale civil wars around the world, the difference in war motivations seems to have shortened the period of a century-long generalization. The indecisive attitudes of the United States of America (USA) in the new world order and its recessive position from aggressive politics lead to new global powers rather than shifts in the global power axis.

However, earlier, this was the result of shifts on the hegemony axis, power change and balance theory. When we talk about the growth of nations and the shift in the axis of power following the industrial revolution, we need to talk about countries' military strength by period. As can be seen in Table 1, which is based on the definition of the Great Forces of Modelski and Thompson, there are shifts in the multipolar structural system.

\footnotetext{
${ }^{1}$ Lecturer at Faculty of Humanities and Social Sciences, İstanbul Kent University, Istanbul-TURKEY, ferdigucyetmez26@gmail.com, ORCID: 0000-0003-1204-2606.
} 
Table 1. Great Powers

\begin{tabular}{ll}
\hline Great Powers & Periods \\
\hline France & $1648-1815$ \\
Great Britain & $1648-1815$ \\
Spain & $1648-1808$ \\
Netherlands & $1648-1810$ \\
Russia & $1714-1815$ \\
\hline
\end{tabular}

Source: Modelski \& Thompson (1988, pp. 44-48).

Namely, when the Westphalian periods are examined, it is seen that the global balance of power is over a few countries. However, while this process progressed towards a unipolar order during the World Wars and the Unipolarity continued during the Cold War, it can be argued that there is a return to the era of Westphalia in the current century. Despite rising interest in establishing lasting peace and spread of new trends in peace studies within the discipline of international relations, "war" as a concept continues to dominate the field and "peace" remains a utopian ideal (Ercoşkun, 2021; Ercoşkun \& Konuralp, 2021).

The system, which started in the 1648 period, was based on the number of soldiers of the armies rather than the military capabilities of the great powers. Sorokin (1937, pp. 543-547), in Table 1 above, scaled the army power of the great powers over five-year periods until World War I and resorted to a power assessment method based on the war times and losses of the countries. The importance of the size of the army of nations is evident in the years when the power in the number of soldiers is the basis for hegemony.

On the other hand, when we look at the world history in terms of the centuries mentioned by Kissinger, it can be seen that the journey of becoming the dominant power in England and America for the last two centuries has become shorter as the adventure of becoming a dominant power has spread over a wide area. For countries that have a strong trade structure, competition has opened the way for a hegemonic power to penetrate other environments and markets. After World War II, the studies conducted on the conceptual framework in which the hegemony of the USA will be established, originating from the USA, had a formative effect on realism.

In this context; Since the Second World War, the US hegemony has come to be constructed through political democracy, economically free market, development models based on proxy and mercenary in defence and socio-cultural communication projects within the framework of modernized understanding.

In Wallerstein's "New World System," the power and structure that will ensure the sustainability of the concept of hegemony take on different forms in terms of every situation and geography. For hegemony, the necessity of being in transnational geographies means more economy, military, technology and equipment for countries that want to remain the dominant power.

"The US put forward a system of hegemony that operates based on realism with the new propositions that emerged theoretically with the end of the Cold War" (Vuving, 2009, pp. 4269). In this context, President George H.W. A concept called "New World Order" was introduced by Bush. However, after September 11, it enabled American foreign policy to focus on the military dimension again.

Let us put together a table by bringing together the elements we have mentioned in the previous section. When the US hegemony is examined, it is seen that it is based on three essential elements. The first of these elements is the global acceptance of the US military and political leadership. The second element is the regulation system proposed by the USA in connection with 
the world economy, which is generally accepted. The last element completes the cultural hegemony system in which the US soft power is represented, through which we advance our article work (Matteo, 2011).

\section{Change Process in the Concept of War and the New World Order}

"If states can achieve the results they want with small, economically and politically costeffective solutions instead of large and expensive conventional military units, war is reborn in another form, and the paradigms we know are radically changed" (Liang \& Xiangsui, 1999, p. 44). Here, the steps taken by states in the name of the rebirth of war are more important for the new world order. At this point, the importance of the hegemony theory emerges.

In times when states and consequently, the concept of hegemony had not yet emerged, definitions of friend, enemy, war and peace emerged. In other words, when the name of hegemony was unknown, people's regional fights and power wars had started. This hegemony was the first steps in the transition to an anarchic order as the number of people increased and different groups emerged.

From an epistemological point of view, it is essential to dwelling on the changes made by countries affecting their international relations with hard power in the conditions of war and the events that led to this change. The changing war conditions in the 19th century are not similar to the wars experienced in the past; the determination of this issue and the pattern of events is the first step of awareness that will shed light in terms of war sciences and theories. The breaking points that cause this change and the effects that cause this change are essential for understanding the future. What did the phenomenon that we call the new concept of war to reveal newly? How valuable is the reshaping of military units in the changing war methods for countries? By which countries has this war concept started to be used in which regions? These kinds of critical questions are significant for the changing global world. An assessment of how new wars differ from the old is particularly important for the defence and security of countries.

The war historian Gutmann says that the current order of hegemony emerged with three wars and that hegemony took its place in the international system. This date marks the year when the balance of power theory mentioned above intersects. We can also hold our theory in our favour by referring to our "Great Powers" table. The 'Thirty Years' War' (1619-1648), the first of the modern hegemonic wars, has a hegemonic structure in which all the great states of Europe (France, Sweden, Poland, the Netherlands, Bohemian Rebels and Austria, Spain) take place and are essential for the literature (Myron, 1988, p.749-770). With this war, the region's people have been under the influence for a long time due to the nature of the new power hegemony and the uncontrolled violence.

Later, in the 18th century, when France and Great Britain were trying to balance power, another war that changed the course of international relations and entered into with an army of thousands of citizens whom France forcibly recruited was Napoleon Bonaparte's hegemonic wars. As in other wars of hegemony, the question of whether French or British domination in European politics was brought to the seas one after another was the breaking point that brought the wars to a high level. "Economic, technological and other developments covering the 19th century and the 19th century transformed the nature of power. On the seas, the British mastered the navy, and on the land, the nature of military organizations changed as new weapons and doctrines emerged with Napoleon's military genius" (Gutmann, 1988, p. 771).

The last of the three great wars mentioned and the closest to us in history is the First World War. This war, which went down in history with the use of eleven new war tools and affected 
the history of warriors with the war literature, has become a state that started in Europe, but its borders reached the whole world.

"The post-war international order shifted and settled into a bipolar order as the American and the Soviets. Whether the foundation of this system will one day be shaken by historical developments and whether it will be destroyed by a hegemonic war using weapons of mass destruction remains a fundamental issue" (Gilpin, 1988, p. 609).

"In 1064, it was legitimized by Pope Alexander II in order to obtain the holy lands with the promise of heaven and the Crusades were organized" (Runciman, 1986, pp. 68-72). Although the Crusades were made after the twelfth century, fighting and military service was not a preferred area for the average Christian until the end of the Middle Ages. For this reason, by the fifteenth century, the mercenaries formed by the poor who fought for money instead of the Feudal Knight were able to show themselves as 'condottiere' in Italy, that is, the mercenary leaders and institutions working on a contract basis used by the Italian city-states. Machiavelli, who lived in Italy in the late 14th and 15th centuries, also mentioned mercenaries in his studies but made negative evaluations about these elements. Machiavelli established this type of militia army in 1509 , but his army was defeated.

As a criticism, he defended his criticism in the form: "A prince must build his country on solid foundations. Otherwise, he will have appointed an evil fate. The main foundations of a state are fair laws and a good army. If a prince builds the defence of his state based on mercenaries, he will never be able to maintain stability and security. Because there is no unity among mercenaries, they seek power and are not loyal (Wallwork, 2004, p. 14).

In his book The Art of War, this army system proposed by Machiavelli has become the essential element of the new system of states, which forms the basis of today's modern political structure established after the 1648 Treaty of Westphalia (Machiavelli, 1999, p. 12). So Westphalian could be considered a turning point. After this agreement, in the 17th century, the number of mercenaries decreased considerably but did not disappear completely.

The rulers thought that their armies were a threat to their security, suspected of being able to do a coup. However, he continued incorporating mercenaries into his armies or hiring one military unit's services from another ruler. "King George hired 30,000 German soldiers to suppress the rebellion that broke out in 1775, the beginning of the American War of Independence and benefited from these mercenaries until 1786 when the war ended" (Gaul, 1998, p. 124).

As countries entered a new era with Westphalia, there were also signals that wars would not disappear, as we mentioned above. The continuation of Europe's civil and religious wars until the industrial revolution caused the death of millions of people. With the industrial revolution, this war was brought to the international arena, opening the door to world wars. Countries that came out of World Wars by losing all their existence were at the turning point for the discovery of a new hegemony. The European states, which were exhausted by the ongoing civil war before the world wars, were opening the door to a new era by using their last energy here.

After these events, it is seen that the regional wars experienced during the Cold War period caused the countries to experience socio-economic and political problems. Therefore, restructuring of defence and security has become inevitable.

The struggle after Westphalia was vital for the hegemony of countries over each other. After 1648, the War of the Spanish Succession of 1700-1713 was an attempt to disrupt the balance of power. After this, in the post-1789 period, Napoleon's competition for domination in the international system and the emergence of the 1804-1815 Napoleonic Wars are entirely to have power in the hegemony order. The wars of hegemony in Europe continued with what Bismarck had done to become the dominant power after 1871, while world wars and local wars were carried to 
the whole world. In these periods, the endless power wars started in terms of the balance of power and the establishment of hegemony. On the other hand, after Westphalia, the Europeans, who tried to get rid of the pressure of the Church, started to feel loyalty to the nation-states of which they were citizens instead of Christianity. As seen in the dates that brought the global wars we have listed, we can say that the multipolar international system is the most unstable structure that can cause war.

While all these wars are taking place, there is a question to be asked. How useful was the use of soldiers in these periods? The use of mercenaries in France and England goes back to the 12th and 14th centuries. This system then spread to Switzerland and Italy during the 13th and 16th centuries. It exists after Westphalia as well as before.

England had a significant advantage over its main rival, France, in this competition. In England, with the 17th-century revolutions, the feudal superstructure was abolished, and an understanding of administration adapted to the needs of capitalist accumulation through the Parliament controlled by a capitalized landed aristocracy became dominant. The bourgeoisation and seizure of power by the landed classes created harmony between financial, commercial and industrial interests and land-based interests (Kaymak, 2016).

England, which had a structure that wanted to take advantage of the economy, was therefore, in the mercenary military system. Until the end of the 18th century, the number of foreign soldiers in the armies of countries such as England and France varied between 20\% and 65\% of the army size according to the needs of the armies. At the end of the 18th century, with the rise of nationalism movements, the changing defence policies caused states not to want mercenaries in their armies. At the end of the 18th century, the British Army was composed entirely of volunteer soldiers. During the American War of Independence (1775-1783), the 20,000 deficits in the British Army was compensated by mercenaries from Russia, the Netherlands and Germany (Singer, 2003, p. 6).

In the years between Westphalia and the French Revolution, when the war issue, which concerns the countries in the war zones, took a new definition with the world wars, military changes were inevitable. In the period following the Second World War, many Western countries, especially the USA, began to examine the causes of war on a scientific basis, and many ideas, approaches or theories were put forward to prevent war. In this context, for example, some pointed to peace education to prevent war and widespread violence. In contrast, others pointed to the need to establish a world state with globalization and international dependence, and some with a central authority (Burton, 1997, p. 12). While some focus on the individual as a unit of analysis and argue that wide-ranging positive changes can occur only through personal changes, others have focused more on structural problems (Negri \& Hardt, 2004) and underlined the necessity of systemic transformation (Galtung, 2004, p. 14).

The former mercenaries, who restructured themselves according to this new situation that emerged in the international environment, started to meet the equipment and material needs of the European armies through the new companies. In the USA, which follows the same tradition as the European one, these private companies have assumed duties in functional areas related to logistics support (Keser, 2018).

As a result, in the last 350 years, in parallel with the social and technological developments, the parties of the war, the aims pursued in the wars, the war strategies and most importantly, the way of the war has undergone significant changes. Wars came out of the monopoly of states and turned into processes in which non-state actors were also involved. After the war, as England did in the early 19th century, the United States achieved hegemony by leading the interstate system 
first and then continuing to restructure and manage this system, which is re-established to reestablish the principles and norms of the Westphalian system.

\section{America's Changing Military Movements}

USA's II. While his involvement in World War II changed the fate of the war significantly, a new era has entered the USA in foreign policy. After World War II, bipolar world order emerged between the USA and the USSR. This power struggle between the two countries has manifested itself primarily in Europe and the Middle East territories (Bilensoy, 2018, p. 53).

This process started in the 1980s with Reagan and Thatcher and gradually spread throughout the 1990s. In this period, the transfer of state-owned functions to the private sector had the opportunity to apply in the military field. This situation played an essential role in the birth and rise of private military companies.

The widespread desire to save and manage businesses faster and more efficiently among Western countries has been a vital defence policy. In the United States, Bill Clinton and George W. Bush saw privatization as a tool in downsizing the armed forces. Bush even went further, making outsourcing among his government's top five priorities (Minow, 2005, p. 6).

The attack of the USA on its territory for the first time after the war of 1812 has been a harbinger of many transformations in the field of security. However, before that, it would be helpful to look at the speech made by US Defence Secretary Donald Rumsfeld in 2001, the day before the September 10, 2001 attack. In this speech, Rumsfeld criticized the Pentagon bureaucracy and emphasized the importance of privatization and outsourcing in the military field. Following the September 11 attacks, military doctrines were once again defined over terrorist activities using such asymmetric warfare strategies, and security policies evolved from the "deterrence" of the Cold War era to the "prevention" of the era of terrorism.

The idea of global hegemonic power is closely related to the effective use of all the concepts mentioned above in a spectrum ranging from industrial production to the arms industry, from mass communication to politics. Technology has been particularly decisive in the emergence of this situation. With the inventions of steam machines and gunpowder, the development of the weapon industry has been necessary for the survival of states. On the other hand, while trying to control issues related to production, finance, politics and society, they have had to plan their economy. Economic problems made a new system approach necessary. States are not conflicting parties in today's wars. Non-state actors are involved in new wars. The replacement of conventional wars by low-intensity wars has gradually weakened states.

Mary Kaldor differentiates between new and old wars but also admits that new wars are not exactly new. However, he states that such a distinction would be useful when developing alternative strategies to prevent wars because we need to know how and to what extent new wars differ from old ones. Wars that Kaldor calls new wars are wars that take place between networks of state and non-state units. Such wars are armed struggles waged by complex legal or illegal organizations that incorporate many transnational relations various global actors such as diasporas, companies, mercenaries, volunteers, non-governmental organizations, religious and ethnic groups, international organizations are among the parties of such wars (Kaldor, 2005, p. 498).

Its exclusion from colonialist politics due to its focus on internal colonization in the field of domination provided a highly favourable position for world leadership in the 20th century. By the Monroe Doctrine that he implemented at the beginning of the 19th century, anti-colonialism, non-interference with other countries' sovereignty and adoption of isolationism policies gave the USA a significant advantage in the systemic chaos environment that emerged during World War I and its aftermath (Gilpin, 1981, p.35). Another aspect of the systemic chaos after World War I 
was the formation of an aggressive alliance of forces such as Germany, Italy and Japan, which realized their national unity through the reconciliation of the traditional ruling classes and the rising bourgeoisie at the end of the 19th century (Wallerstein, 1974, pp. 387-415).

The ideology necessary for the US to assume hegemonic leadership to lead such a restructuring became increasingly evident in the interventionist liberal experience of the Roosevelt era in the 1930s. The ideology of Americanism gave the US an advantage for world leadership in a world dominated by monopoly capitalism (Glovanni, 1993, pp. 148-185).

Studying the Kennedy-McNamara period, Bernard Brodie said that systems analysis and technological superiority were exaggerated and that they separated war from its historical and political environment. That strategy constituted one of the causes of the Vietnam fiasco. During the Iraq war, it was clear that advanced technology destroyed Saddam's conventional armed forces in a matter of days (Petraeus, 2010, pp. 116-114).

We can show the process that started with the Vietnam War as the turning point of traditional war theories and the beginning of the military change that we have mentioned so far. America has taken the definition of war to another dimension with the war tactics that it changed with the sad end of the wars it entered.

With the peace period established over a bipolar balance of power as a function of the resharing of the world and nuclear power after the Second World War, some concepts were redefined on the one hand, and new concepts were included in our lives on the other. The Cold War period, which took place as both sides could not directly enter into hot conflict with each other due to the arms race, in which the two blocs had weapons balanced between the two poles and to balance the power of each other, reducing the possibility of traditional inter-state wars, while wars took place in non-central countries where the great powers avoided contact with each other. While the possibility of total war in the world is decreasing, the integration that European states have begun to establish within themselves and the peace in this geography, the replacement of conventional weapons with nuclear weapons, the Western world reactions to the Vietnam War, low birth rates, shrinking families and the expansion of democratic politics, the death of soldiers it meant that the idea could no longer be sustained for Western states. In this process, it is observed that with the technological developments and the new weapon systems developed, there is no need for a large amount of manpower on the battlefield and behind the front, as in the period of total warfare.

The United States fought in Vietnam for nine years with a build-up of 550,000 soldiers, resulting in the loss of 50,000 troops, and had to leave the country. The Soviet Union, which invaded Afghanistan in 1979, had to withdraw from the country nine years later, with more than 30,000 casualties (Gaddis, 2006, pp. 432-435). The resistance in Afghanistan was a mixed guerrilla organization. Although the insurgents did not have serious training, could not cooperate among themselves, and never gathered more than one company and carried out a massive attack, they were able to ensure the withdrawal of the Soviet Army (Bamett, 2004, pp. 25-26).

The complex weapon systems that started to be used during the Vietnam War made the technical assistance of civil organizations essential in the advanced parts of the battlefield. During this war, two firms named 'Vinnell' and 'Pacific Engineers and Architects' provided logistical support to the American army and trained the South Vietnamese police force and armed forces (Fidler, 2020).

In the event of a real crisis and armed conflict, the question marks about how efficient combat-oriented services can yield results have been eliminated when the practices used in the Vi- 
etnam War were found successful by the military. The Vietnam War experiences contain important data showing how the private sector can play a role in military activities. As the number of combat units sent overseas to a foreign country increases, the number of bases where they will be deployed also increases. These units need bases where they can store their ammunition, repair and repair aircraft and military vehicles, rest, treat the wounded and sick, and command and control their operations. Another factor that causes the increase in the number and capacity of these bases is the high firepower on which the American war method is based, and the need for high ammunition, and the maintenance, repair and spare parts requirements of technologically advanced weapons that use them. A wide range of services ranging from all this base construction to providing the logistics services required by combat units required much military personnel to work in non-combat missions. Under these conditions, more than 35 private companies have undertaken the majority of the work required to construct defence facilities in Vietnam. This situation allowed the Pentagon to send more combat soldiers to the region instead of sending engineers, logistical support and transportation personnel. The lesson taught by the Vietnam War to the military is to outsource wherever possible. Thus, while the private sector could do what it did best, the military could concentrate its personnel power on combat missions.

Thus, this lesson learned from the practices in the Vietnam War, on the one hand, the widespread privatization policies of the Reagan era and the modernization of the army with sophisticated weapon systems, on the other hand, constituted the two most significant factors that increased the dependence of the military on the private sector in the first Gulf War in 1991 to a level never before in history.

"The desire of the state to shrink its armed forces, to cut costs by resorting to market mechanisms, as well as the increased need for military services and the existence of civilian technology that is applicable to military needs, produced" and ready on the shelf "made government members and decision-makers to believe that privatization of some military services was inevitable (Kinsley, 1988, p. 47).

Increasingly, the US military uses private contractors, that is, private companies that are often led by former officers and provide training, recruitment, and other support and operational services on or off the battlefield. Such professional private soldiers, hired by contract, replace active soldiers. With these contract implementations, the distinction between rental support and the rental army is blurred. When the Pentagon's aim to equip the army with state-of-the-art weapons systems and the means to obtain the necessary financial resources by downsizing the armed force personnel, the result will be further privatization of military services.

The new system, low-intensity threats compared to conventional warfare, brought the necessity of downsizing the armed forces and making them flexible. With the reduction made in the 1990 s, the number of active personnel of the American armed forces decreased by $30 \%$. However, due to the increasing operational pace, it was ensured that, as much as possible, the works that were not considered as the essential functions of the military were transferred to the private sector, and the currently active military personnel were kept in combat missions (Vernon, 2014, p. 373).

While the USA had 711,000 active soldiers in its army during the 1991 Gulf War, this number dropped to 487,000 during the 2003 Iraq War. Private military companies partially covered this personnel shortage. As of September 2007, the number of US troops in Southwest Asia was 160,000 , while the number of employees working in the services provided by the US army through tender bids in this region was 196,000 (Commission on Global Governance, 1995, p. 45). 
There are three reasons experts agree on the emergence of the private military sector. The first is the privatization wave brought about by the free market economy after the Cold War. The second is the need for work of the surplus military workforce created by the shrinkage of armies. The third is the reluctance of the great powers to intervene in the developing World (Singer, 2004, pp.1-4). On the other hand, the US, which needs public support to achieve its long-term strategic goals, has chosen to use private military companies for support, training and military purposes in order to reduce the military losses that can cause political concerns. As a result, companies in the private military sector have entered the race to win tenders, and many countries around the world have been hasty and careless when recruiting citizens. This environment and conditions made the Iraq War the peak of the privatized war.

The end of the Cold War initiated a worldwide military downsizing movement. The US Army decreased by a third compared to the Cold War era. The British Army has also been the least outnumbered for two centuries. In addition to this massive downsizing in the army, advancement and promotion opportunities for professional officers were also reduced. The world market is almost overwhelmed by military personnel, and this situation has created an excess supply of military labour for the private military industry.

Compared to current state armies in 1989, it seems that roughly 7 million fewer soldiers were accommodated. This downsizing has created an excess supply in terms of trained military labour. Besides, with the introduction of Soviet weapons, there was an extreme abundance of weapons. On the other hand, conflicts have increased with the spread of cheap light weapons. Only 2 million people in East Africa were killed with these weapons (Singer, 2001, p. 90).

Thus, the private military labour pool has expanded and become cheaper for both conflict groups and private companies. Some demobilized troops, such as the Soviets Alpha Alliance and the South African '32nd Reconnaissance Battalion', formed their own Private Military Companies without ever disbanding. The number of people working in the field of private security in the USA has reached three times the number of police officers and five times in Hong Kong. The number of employees in the private security market in England is around 500,000. On the other hand, the number of personnel working in the police organization is 136,000 (Singer, 2004, p. 2).

Private Military Companies, which started after the Cold War, especially with the emergence of the international operations of Russia and America, differ from other examples in history with remarkable differences. For this reason, it is necessary to examine the last 30 years more closely to understand that these companies, which have a particular share in the global economy, have become global companies rather than mercenaries. Besides, due to the thought that threats and needs have decreased in the post-Cold War period, the fact that some of the service areas, which were previously the monopoly of the state armed forces, were left to the responsibility of companies operating in free-market conditions, especially as a result of the trend of downsizing the armies in Europe, has further increased instability and internal turmoil in the countries.

Suppose we summarize the development process, the new conflict areas that emerged after the Cold War, the shrinkage and professionalization of armies, the emergence of low-intensity conflicts, technological development in weapon systems, information, cyber warfare, etc. We can determine that the number of private military companies and their influence has increased enormously after 1990 (Deborah, 2005, p.17). The most common use of military companies in the Iraq War. Although not foolproof, more than 60 companies and more than 20,000 employees have been operating in Iraq.

The asymmetric war that emerged after the US intervention in Afghanistan became even more critical with the transformation of an asymmetric war into a hybrid war following the Iraqi 
intervention and the conflicts in Syria and making it widespread and deep with the strategy of proxy wars. America has emerged as the only powerhouse that shaped the international environment. America started to implement policies of downsizing rapidly within the framework of this new security environment. The Land Forces personnel number, which was 1.5 million in 1969 , immediately decreased to 750 thousand by 1991 . As a result of the radical decrease in the number of US Armed Forces personnel, the number of personnel, which was 3 million 302 thousand 104 in 1954, decreased to 1 million 339 thousand 36 in 2019 (Mandel, 2019: 42).

On the other hand, the USA had 711,000 active soldiers in its army during the $1991 \mathrm{Gulf}$ war. During the 2003 Iraq War, this number dropped to 487,000. Private military companies partially covered this personnel shortage. The amount spent by the US military in the 2006 budget for tender bids is 300 billion dollars.

As of September 2007, the number of US soldiers in Southwest Asia was 160,000, while the number of employees working in the services provided by the US army through tenders in this region was 196,000. In this new environment, some weak states found themselves deprived of well-trained and equipped armies and vulnerable. As a result, they could not provide security and stability within their borders. Also, while the USA signed contracts with these companies to provide more non-combat services; Weak states in Africa or Asia pay to carry out conflicts themselves and neutralize opposing groups.

While there were nine companies with federal internal security contracts in the USA in 1999, this number increased to 3512 in 2003 and 33.890 in 2006. Since 2000, the US has paid 130 trillion to private military companies. Annual federal expenditure on this sector in 2015 is estimated to be 170 trillion dollars (Paul, 2006, pp. 1-17).

The USA started a period in military services has traditionally been providing military training services to foreign governments. In 1975, when Vinnell Corp signed a $\$ 77$ million contract to train the Saudi Arabian National Guard to protect the oil fields, a US company entered into an independent contractor for the first time with a foreign government to provide military services (Doug, 2000).

One of the functions that private military companies fulfil is that they can easily infiltrate areas where national armies are restricted or banned on behalf of powerful states. Colombia is the most typical example of this situation. Congress limited the number of American troops (approximately 400 soldiers) and the jobs they could perform in this country. As a result, Colombia became a region where seven different private military companies played a role in the civil war and did different jobs. Many of them have worked with the American government and have taken on many roles that the government could not. Private military companies acted with Colombian military units in the civil war, while American soldiers were only involved in combating the drug trade. There have also been private military companies working to benefit multinational oil companies (Singer, 2004).

The notion that the impact of the loss of private military company personnel on domestic politics and its consequences during deportation operations will not have as negative consequences as the military losses in the official armies is seen as a separate policy tool for the governments of the country.

According to the Defence Report of the USA, new generation wars, global terrorism and border security are seen as threats to the USA in the next 20 years. In addition to these, the reconstruction of problematic countries, particularly Iraq and Afghanistan, continues. In addition, the integration of states such as Iran and North Korea into the international system and measures to be taken against diplomatic problems with countries such as Brazil, Russia, India and China are included (United States Defence Report, 2010). 
As examined in the above lines, the process of monopoly in the areas of the state's power to use force as well as the means of the use of force, their creation, keeping and allocation is an evolution that must be completed in order to become a sovereign state and was not the last point to be reached in this evolution (Sayın \& Akbulut, 2018). First of all, the developing combat technologies and the military restructuring process required by it, and then the republican ideology, in which the relations between the state and the individual were shaped with a new understanding, provided the formation of the modern state (the nation-state as it is called today), which seized the monopoly of coercion as we describe it today. Therefore, the changes in the conditions affecting the transformation process after this point and the emergence of different needs and different possibilities as a result of this would very well cause the sovereign state to enter a new transformation in the control of the means of use without losing this title. The changing concept of war has constituted the underlying phenomenon of the change of 200 years of settled structuring in this area, that is, the process of the re-emergence of the privatized military industry.

Besides, it is a separate fact that military companies, which are used for military and security purposes, generally engaged in dangerous missions, adversely affect the process, violence and duration of the war with the incidents and hot conflicts they are involved in. This negative impact on the war not only increased civilian and resistance losses but also increased the losses of the US and coalition armies and the losses of private military company employees.

As Huntington said, the community approves of the use of military professionals for violence management for purposes it approves (Huntington, 2006, p. 17). With the proliferation of private military companies and obtaining a significant portion of the human resources required for these companies from former army personnel, Huntington's perception that military professionals act in line with the goals approved by society and use their abilities may change. Besides, this situation may cause the perception that the army works for its country and society. To put it more clearly, the perception in society that military professionals are managing violence only for the purposes they approve will weaken as military professionals bring their knowledge and experience to the private military market. It will also be able to reveal the idea that this group acts in line with its interests rather than the interests of society. This perception may change significantly in societies with a strong perception that the military profession is sacred and value-laden.

\section{Conclusion}

It can be said that the USA created American defence tactics in the 20th century with its foreign policy traditions. The presence of multiple facets of American foreign political culture has also made this state a force that fights against global problems and leads the international community. The US foreign policy has become ordinary, emerged, and the democratic culture has been moved away. As we can see in the September 11 example, the adverse external developments to be experienced have pushed the US to more unilateralism. After this development, America has made significant changes in its defence policy.

The last decade of the 20th century saw developments that required the state to reorganize the means of the use of force and came to life in two different dimensions. The first of these is that, as a result of the end of the Cold War, states have virtually eliminated the risk of a highintensity conflict - a classical state of war, as well as the emergence of other risks to international security and the threat of a new war.

In the global sense, the downsizing of the armies after the Cold War, privatization and widespread use of outsourcing in order to decrease the costs have prepared the ground for the formation of private military companies. The radical change in this area is the September 11 Incident, in which the perception of international terror and security has changed. The Afghanistan 
intervention and the Iraq War have been the "Golden Age" of private military companies. The USA used them in the Afghanistan and Iraq wars closer and closer to the front line than ever before. With the roles they played in the Iraq and Afghanistan operations that marked the first decade of the 21 st century, the private military entrepreneurs, who came to the stage as an essential component of military affairs in a way that the public was not accustomed to and expected, became the pioneer of the international process.

In line with the data we are trying to put forward, we can say that, before the concept of the region called the geography of war was not yet in the middle, unstable transition periods took place on the real world axis. Kalevi Holsti (1991) found out in his study of the wars between 1648-1989, and the result revealed by the findings is that more than ninety per cent of the wars in the world are the wars of the Europeans. In other words, there are findings that Europeans were involved in almost all wars in the last four centuries on the global axis.

When we proceed with the historical light that Holsti put forward, in the war rules of the Westphalia period, the radical decisions made by the leaders and commanders and the fact that the people were involved in the chaos that was declared collectively, globalization was closely related both economically and socially. Although the people, who are intertwined with wars, have experienced a certain period of economic and cultural suffering, the obligation to obey the decisions made by the leaders only paved the way for increasing chaos and mass movements. In time, although the soldiers and armies that were chosen from among the people continued to be established, the people were in a state of relief with the establishment of professional units.

We need to look closely at the subject we are trying to explain. That is to say, the defence budgets of global powers also give important clues about the strategic perceptions of the elements involved in the struggle for global hegemony. On the other hand, these budgets made it possible to make a proportional analysis of the state's problems as security threats. However, we can say that the budgets are inversely proportional to the number of soldiers, as the increasing budgets today are not only for military power but also for investment in new defence mechanisms.

The Pentagon's request from the US Congress for the 2020 defence budget is around $\$ 718$ billion. This figure is $\$ 33$ billion more than in 2019. It corresponds to a 5 per cent increase proportionally. While the core part of the budget consists of $\$ 544.5$ billion, it seems that $\$ 9.2$ billion is allocated for the emergency border security fund and $\$$ billion for the overseas operations fund. The proposed figure for 2020 will also constitute $3 \%$ of the US GDP. On the other hand, the declining number of military assets explains that these investments are related to the technology and defence industry. So, as a result, America's changing defence budget no longer focuses on warfare in space and hypersonic missiles as defence, not military.

The age of total war had come to an end, as the forms of power and hegemony began to differ in the technology era when the old wars were left behind. After the European states gained much experience, and the historical data was revealed, the re-manifestation of these experiences in the field made these changes inevitable. The fact that the USA lost war many times during the changing power profile and its reflection on the economic tables confirmed the theses put forward by Clausewitz. Countries trying to keep the dynamics in domestic politics alive with the attitude of the people, as a result of these reservations, opted to privatize their armies, which are war institutions and have been to achieve success by integrating them with technology. In our study, we tried to prove the cost of wars to the USA and that the new war concept is inevitable by comparing the country's economic data in terms of soldiers, data, war expenditures and domestic dynamics. 
As Joseph Nye said, Intelligent power; is neither hard power nor soft power. Smart power is the use of both hard and soft power with a unified strategy to achieve goals. Smart power requires both a strong army and investment in alliances or partnerships at all levels that will increase the country's influence. The combination and use of the two is diplomacy and the art of war. The concept of art meets this situation very well because deciding and applying power in which state, where and how to use it requires intelligence, talent and experience.

\section{References}

Barnett, T., (2004). Pentagon's New Map: The Military in the 21st Century, New York: Berkley Books.

Bunker R., \& Steven M, (1999). "Executive Outcomes: Mercenary Corporation OSINT Guide" (July 1999), http://fmso.leavenworth (date of access: 05.09.2020).

Burton, J., (1997). Violence Explained, New York: St. Martin's Press.

Bilensoy, İ., (2018). George W. Bush ve Barack Obama Dönemlerinde Terörizme Karşı Uygulanan Politikaların Karşılaştırılması, Lectio Socialis, 2(1), 53.

Christopher, K., (2006). Corporate Soldiers And International Security, The Rise Of Private Military Companies, London \& New York: Routledge.

Commission on Global Governance, (1995). Our Global Neighbourhood, The Report of the Commission on Global Governance, Oxford: Oxford University Press.

Petraeus D. G., (2010). Counterinsurgency Concepts: What We Learned in Iraq, Global Policy, 1(1), 116-117.

Deborah, A., (2005). The Market Force: The Consequences of Privatizing Security, New York: Cambridge University Press.

Doug B., (2000). Messiahs or Mercenaries? The Future of International Private Military Services, International Peacekeeping, 7(4), 129-144.

Ercoşkun, B. (2021). On Galtung's Approach to Peace Studies. Lectio Socialis, 5 (1), 1-8. DOI: 10.47478/lectio.792847

Ercoşkun, B, Konuralp, E. (2020). Change, Transformation, and Trends in Peace Studies. Dumlupinar Üniversitesi Sosyal Bilimler Dergisi, (66), 187-199. Retrieved from https://dergipark.org.tr/tr/pub/dpusbe/issue/57463/739123

Fidler S., With Armed Forces Stretched, Governments Face Hard Lobbying, Financial Times, http://www.financialtimes.com/archive/html (date of access: 24.07.2020).

Gaddis, J. L., (2006). The Cold War: A New History, Politique étrangère, Institut Français des Relations Internationales, 2(71), pp.432-435.

Galtung, J., (2004). Peace by Peaceful Means, Sterling, VA: Pluto Press.

Gaul, M., (1998). Regulating the New Privateers: Private Military Service Contracting and The Modern, Marque and Reprisal Clause, Loyola of Los Angeles: Law Review.

Gilpin R., (1981). War and Change in World Politics, Cambridge: Cambridge University Press.

Glovanni, A,. (1993). Three Hegemonies of Historical Capitalism, New York: Cambridge University Press.

Gutmann, M., (1988). The Origins of the Thirty Years War, Journal of Interdisciplinary History, Cilt. (18)2, p. 771.

Hardt M. \& Negri A., (2004). Çokluk: İmparatorluk Çağında Savaş ve Demokrasi, çev. Yıldırım Barış, İstanbul: Ayrıntı Yayınevi.

Harris, P., "How US Merchants of Fear Sparked a 130 Thousand Dolar Bonanza", http://www.informationclearinghouse.info/article14909.htm,(date of access: 01.11.2020).

Huntington, S. (2006). Military and State: Theory and Politics of Civil-Military Relations, Salyangoz Press: İstanbul.

Kaldor, M., (2005). Old Wars, Cold Wars, New Wars, and the War on Terror, International Politics, 42(12), 498.

Kaymak, M. (2016). Hegemonya Tartışmaları Işı̆̆ında İngiliz ve Amerikan Hegemonyaları: Yönlendirici Hegemonyadan Kural Koyucu Hegemonyaya, Hacettepe University Journal of Economics and Administrative Sciences, 34(1), 63-92.

Keser, A., (2018). "Özel Askeri Şirketlerin Küresel Yayılımı ve Geleceği." https://setav.org/assets/uploads/2020/02/R154.pdf, (date of access: 10.09.2020).

Kinsley, D. R., (1988). Hindu Goddesses, Berkeley: University of California, p.47.

Kissenger, H., (1994). Diplomacy. New York: Simon \& Schuster's.

Lewis Gaddis J., (2004). Surprise, Security, and the American Experience, Harvard University Press. 
Liang Q., \& Xiangsui W., (1999). Unrestricted Warfare, Beijing: Literature and Arts Publishing House.

Machiavellı N., (1999). Savaş Sanatı, Çev. Berna Hasan, İstanbul: Özne Yayınları.

Mandel, R., (2019). The Privatization of Security, International Student Association 41thAnnual Convention, Los Angeles: United States Publish.

Matteo, P., (2011). Power and Its Forms: Hard, Soft, Smart, The London School of Economics and Political Science, 2(4) $12-45$.

Minow M., (2005). Outsourcing Power: How Privatizing Military Efforts Challenges Accountability, Professionalism and Democracy, Boston College Law Review, 46(5), 1-39.

Modelski G., \& Tompshom G. (1988). Seapower in Global Politics 1494-1993, Seattle: University of Washington Press. Myron, L., (1988). Marketing Literatüre Review, Western Carolina University, 1(1), pp. 749-770.

Paul, E., (2006). A Survey of the Theoretical Economic Literature on Foreign Aid, Crawford School of Public Policy, 20(1), pp.1-17.

Rebecca, R. V., (2004). Battlefield Contractors: Facing the Tough Issues, Public Contract Law Journal, 33(2), 369-421.

Rothenberg, G. G., (1988). The Origins Causes and Extension of the Wars of the French Revolution and Napoleon, Journal of Interdisciplinary History, 18(2), 771- 793.

Runciman S., (1986). Haçlı Seferleri Tarihi, Çev. Fikret lşıltan, Ankara: Türk Tarih Kurumu Basımevi.

Sayın, H., \& Akbulut, E., (2018). Transnational Immigrant Communities and Ethnic Solidarity: The Case of Samsun and Syrian Circassians, Journal of Social Sciences Institute/Sosyal Bilimler Enstitüsü Dergisi, 8(16), 371-394.

Singer P. W, (2004)., The Private Military Industry and Iraq: What have we learned and where to Next? Geneva Centre for the Democratic Control of Armed Forces Policy Paper, 2(1), 1-4.

Singer, W. P., (2001). Corporate Warriors: The Rise and Ramifications of the Privatized Military Industry, International Security Publisher (23)3, 90.

Sorokin, P., (1937). Social and Culturel Dynamics, New York: American Book Company.

United States Defense Report, (2010). Know Your Military, https://www.defense.gov/KnowYourMilitary, (date of access: 22.07.2020.)

Vernon, R., (2014). Bureaucratic Structures in Urban High Schools, San Diego State University, ProQuest Dissertations Publishing.

Vuving, A. (2009). How Soft Power Works, Associate Professor, Asia-Pacific Center for Security Studies, American Political Science Association annual meeting, Toronto, 8(3), 42-69.

Wallerstein, I., (1974), The Rise and Future Demise of the World-Capitalist System: Concepts for Comparative Analysis, Comparative Studies in Society and History, 16(4), 387-415.

Wallwork, R., (2004). Operational Implications of Private Military Companies in the global war on Terror, School of Advanced Military Studies the United States Army Command and General Staff College, Kansas, USA: Fort Leavenworth

Wu, I., "We All Contribute to a Nation's Soft Power", (July 2018), https://www.realclearworld.com/articles/2018/02/08/we_all_contribute_to_a_nations_soft_power_112703.html, (date of access: 15.08.2020). 